\title{
Teaching methodology for the acquisition of competences in students of Physical Therapy of the Polytechnic University of Amozoc
}

\section{Metodología de enseñanza para la adquisición de competencias en estudiantes de Terapia Física de la Universidad Politécnica de Amozoc}

\author{
SORIANO-PORRAS, Dulce Maria $\dagger^{*}$, MARTINEZ-TELLEZ Rubelia Isaura and APAN-ARAUJO, \\ Karla Cecilia
}

Universidad Politécnica de Amozoc

ID $1^{\text {st }}$ Author: Dulce María, Soriano -Porras / ORC ID: 0000-0001-7398-0693, Researcher ID Thomson: E-8233-2018 arXiv Author ID: 8GO6IR-3HFFHH

ID $1^{\text {st }}$ Coauthor: Rubelia Isaura, Martínez-Tellez / ORC ID: 0000-0003-0164-066x, Researcher ID Thomson: E-8229-2018 arXiv Author ID: 6YNFU8-XHIM03

ID $2^{\text {nd }}$ Coauthor: Karla Cecilia, Apan-Araujo/ ORC ID: 0000-0003-3373-226x, Researcher ID Thomson: E-8338-2018, CVU CONACYT ID: 896703

DOI: 10.35429/JHEW.2019.5.3.17.22

Received September 30, 2019; Accepted December 30, 2019

\section{Abstract}

This study addresses the design of an active teaching methodology for sixth-semester students of the Physical Therapy degree at the Polytechnic University of Amozoc. The intervention by the teacher corresponds to the design of a regulatory methodology and guidance in the learning process with specific purposes, selection of spaces, resources, strategies, experiences and coherent activities within the context of the subject of Clinical Practice I that stimulates students and allows them to interact and integrate the three types of knowledge: conceptual, procedural and attitudinal, linking theory and real practice, creating productive environments that allow adjusting to the phases of significant learning within a collaborative work. We present an explanatory, interventional, longitudinal, prospective, prolective, unicentric work through the application of a teaching methodology, the objective of which is to demonstrate its impact on the acquisition of general and disciplinary competences through an evaluation that supports their achievement

Competences, Methodology, Physical Therapy

\begin{abstract}
Resumen
El presente estudio aborda el diseño de una metodología de enseñanza activa para el aprendizaje en alumnos de VI cuatrimestre de la licenciatura de Terapia Física de la Universidad Politécnica de Amozoc, La intervención por parte del docente corresponde al diseño de una metodología reguladora y guía en el proceso de aprendizaje con propósitos específicos, selección de espacios, recursos, estrategias, experiencias y actividades coherentes dentro del contexto de la asignatura de Práctica Clínica II mismo que estimula a los estudiantes y les permite interactuar e integrar los tres tipos de conocimientos conceptual, procedimental y actitudinal vinculando la teoría y la práctica real, creando ambientes productivos que permiten ajustarse a las fases del aprendizaje significativo gradualmente dentro de un trabajo colaborativo, por lo que se realizó un estudio de tipo: explicativo, intervencionista, longitudinal, prospectivo, prolectivo, unicentrico mediante la aplicación de una metodología de enseñanza cuyo objetivo es demostrar su impacto en la adquisición de competencias generales y disciplinares mediante una evaluación que sustente el logro de las mismas
\end{abstract}

Competencias, Metodología, Terapia Física

Citation: SORIANO-PORRAS, Dulce Maria, MARTINEZ-TELLEZ Rubelia Isaura and APAN-ARAUJO, Karla Cecilia. Teaching methodology for the acquisition of competences in students of Physical Therapy of the Polytechnic University of Amozoc. Journal Health, Education and Welfare. 2019. 3-5: 17-22

\footnotetext{
* Correspondence to Author (dulcezully@ gmail.com)

$\dagger$ Researcher contributing as first author
} 


\section{Introduction}

Education is understood as the activity that consists in guiding and providing, from the outside, what is necessary to build. Currently, the work of every teacher is "to focus intelligently the educational task" (Barrio, 2007, p. 118). This allows the teacher to work in a planned and intentional way, seeking to develop physical, intellectual and emotional faculties. Therefore, the teacher is required to implement a teaching methodology in which to reflectively select strategies, resources, spaces and contents that are involved in the learning phases of students, adapting to objectives and allowing the student to integrate knowledge for the achievement of significant learning.

For this reason, 25 students of the subject Clinical Practice II of the Polytechnic University of Amozoc were selected, so that they could integrate a physiotherapeutic diagnosis and offer a treatment. We designed a learning methodology focused on responding to the intervention model of Physiotherapy, achieving a method aided by techniques that demand the active intervention of the student in collaborative work and favor the clinical reasoning that allows the development of transversal and disciplinary.

Does the group improve the development of transversal and disciplinary skills with the application of a teaching methodology by the teacher?

\section{Theoretical Framework}

The objective of the teacher is to educate in a significant way, taking care of the aspects of the information content structure in terms of hierarchy and interrelationship, as well as how to transmit them, strategies or didactic techniques to be used for the fulfillment of the teachinglearning objectives for the acquisition of declarative, procedural and attitudinal-value knowledge.

All the aforementioned considers the student's learning phases in a significant way as proposed by Shuell in 1990, or levels proposed by Korthagen and Lagerwet (1995), who share common criteria since they emphasize experiences as a source of knowledge-building and the importance of language in the transformation of an image into a theory.
As well as the relationship with the teaching strategies in charge of the teacher capable of providing strategic teaching, which consists in helping and adjusting according to how the progress in the constructive activity of the students occurs. "The teacher must focus on students looking for complex contextualized learning situations, based on the development of application and problem solving abilities. Disciplinary content will be the vehicle for planning various learning and teaching strategies that achieve the integration of theoretical knowledge, that is, the what with the how (procedural knowledge) and the why (contextualized conditional knowledge)" (Fernández, 2006, p. 40). Resuming the importance of the moment of presentation of strategies because it allows the teacher to use them and develop them properly to intervene in the cognitive processes of the students (DíazBarriga and Hernández, 2002 p.144).

Bearing in mind the above, we retake method design implemented by the teacher, which supposes a succession of actions ordered by more or less complex procedures and techniques, which, if structured properly, generates significant learning. (Monereo, 1999, p11) thus, "the teaching method implies the indispensable interrelation of teacher and student, and in the process the teacher organizes the student's activity on the object of study and as a result the student assimilates the teaching content." That is to say, "it is a system of actions aimed at organizing the practical and cognitive activity of the student with the aim of solidly assimilating the contents of education" (Navarro and Samón, 2017. p.3).

Through its characteristics they guarantee good results, which are mentioned below:

1. Flexible and adapted to the students' capacity, intelligence, preparation, needs and interests, in continuous transformation, confronting them to a situation without frustration.

2. Economic in relation to time and effort of the students to learn better and without fatigue. That is, the cognitive imbalances caused should not be so great that they lead the student to abandon the learning task, instead of accommodating." (Moreira, 1997, p. 15) 
3. Clearly express the objectives for each activity and the moment in which it will be applied.

4. Progressive, planned and cumulative, since each phase or stage of the work completes and consolidates the previous one and prepares the ground for the next. (Matoos, 1985, P.45)

5. Creative and innovative that proposes different types of work (Fernandez, 2006, p.54)

Therefore, it is used so that the students react to the learning process which uses techniques as auxiliaries if it is applied to the appropriate circumstances and at the precise moment orients each step or stage that must be addressed, while walking the path indicated in the procedure it points out the ways of going along the way, observing, discussing, experiencing, comparing, collecting data, classifying, discriminating, it provides orientation on how to travel the road, step by step (Moreno, 2003, p. 87-93)

In this way, students will be given effective strategies to learn and improve the understanding of academic texts, composition, problem solving through reflection. Regulating their learning process "means that the person is able to achieve their learning objectives" (Huerta, 2007, p. 4)

In the Physiotherapy field, the physiotherapist assists in the follow-up of a model of intervention that focuses on the identification and treatment of health disorders through five stages:

1. Assessment: references, preparation of the physiotherapy record, physical examination and registration

2. Analysis: Problem identification and diagnostic elaboration

3. Formulation of the Physiotherapy program

4. Program application

5. Evaluation

Which requires a teaching method structured by the teacher that favors the student in terms of the integration of different types of knowledge.
That allows the understanding of the anatomy, biomechanics, alterations, analysis of the identification of a functional limitation to obtain a physiotherapeutic diagnosis, that is, searching for the causes of the alterations in the structure and work on them and its strength, flexibility, resistance, coordination, balance and proprioception attributes (Gallego, 2007, p180). As well as being immersed in a bio-psychosocial approach from the corporal, individual and social perspective, based on the International Classification of Functioning (Jiménez, 2016, p 46)

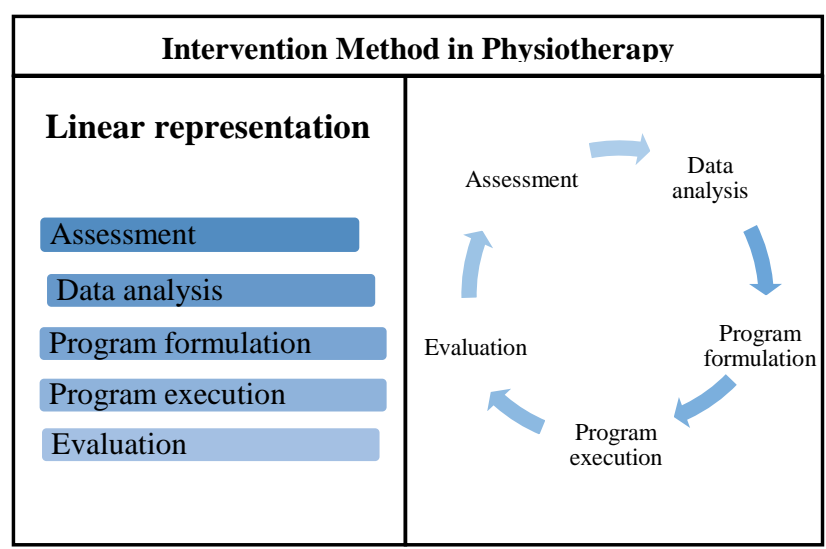

Table 1 Intervention Method in Physiotherapy Source (Gallego, 2007, p. 167)

The aforementioned allows identifying the level of learning, since the student progresses from a level of understanding to evaluation, through the integration of knowledge.

This is when working with the active methodology for the formation of competencies strengthens the discipline and applies to different contexts "in an action plan that consists in the creation of a learning process in a context, time and function of the specific objectives for a project. "The role of the teacher is not restricted to creating conditions and conveniencies, but rather explicitly guides the activity performed by the students." (Arceo, 2003, p. 7)

"In this framework, the two main tasks of the physiotherapist teacher are: planning and designing experiences and learning activities consistent with the expected results, taking into account the necessary spaces and resources that encourage guiding, motivating and helping students in their meaningful and context-based learning process. 
The challenge lies in broadening the methodological repertoire of the different strategies and experiencing their application in educational practice, thus achieving the appropriation and adaptation to new circumstances and possibilities of these methods" (Fernández, 2006, p. 44). (Zarzar, 1992, p.99) also states that "techniques are not sacred as instruments; modifications and adaptations that the coordinator considers necessary for the achievement of the objectives may be conducted, the existence of support strategies must also be taken into account which "are characterized by focusing on the auxiliary processes that support learning, improving the material and psychological conditions that occur." (Montoya, 2010, p. 208, Pozo and Gómez, 2006, p. 56)

\section{Methodology}

In the Polytechnic University of Amozoc, a type study was implemented: explanatory, interventional, longitudinal, prospective, prolective, unicentric by applying a teaching methodology based on strategies and techniques such as clinical case summary, model, comparative table, workshop and discussion, which were integrated to address the topic corresponding to the orthopedic area in Physiotherapy.

The population corresponded to 25 students of Clinical Practice II of the major in Physical Therapy during the period JanuaryApril 2019. To carry out the research project, five work sessions were required and later evaluated with a validated instrument with a Crombach alpha of 9.51 and a general and disciplinary rubric related to competencies adapted from MEC. Campos, (2010)

\section{Module I}

It included 1 session of 2 hours, in which the general instructions and allocation of didactic resources were given; Internet service, mobile devices, digital texts, anatomical model and teams of 5 people.

A clinical case compiled from a bibliographic source was provided, which was adapted in phases to the subject corresponding to the area of orthopedics in Physiotherapy.
So that as a team they could read it and work the first two techniques of the proposed methodology through the use of established resources, while the teacher supervised and carried out the assessment in competencies.

Phase I. Anatomical models were used in which the students placed the structures and exemplified the function of the anatomical segment mentioned in the clinical case; it was subsequently accompanied by a summary in which they would describe the anatomy and biomechanics of the segments involved.

Phase II of the clinical case provided characteristics of the current condition. The students used the computer lab for the elaboration of the comparative table where they identify the nociceptive characteristics of the tissues and was later sent via email to the teacher.

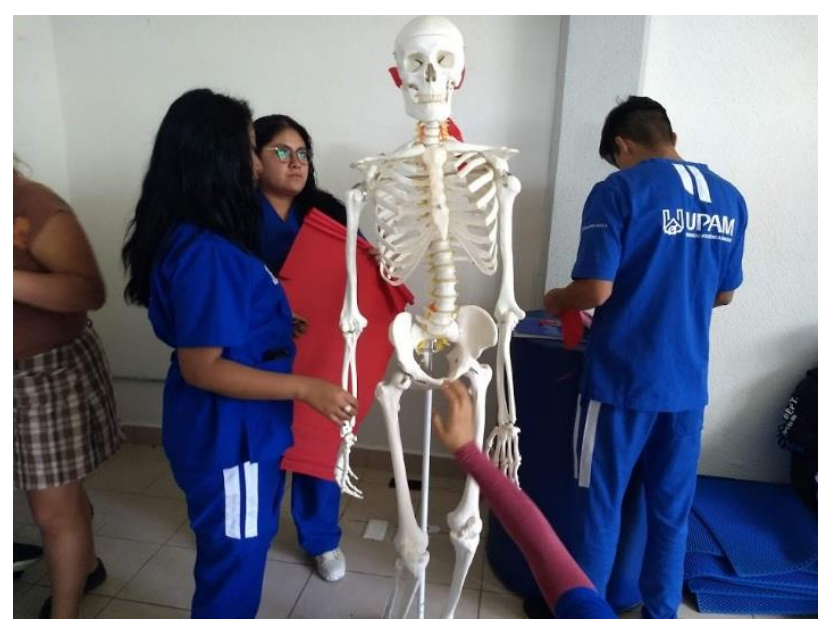

Figure 1 Anatomical model

Source: Self Made

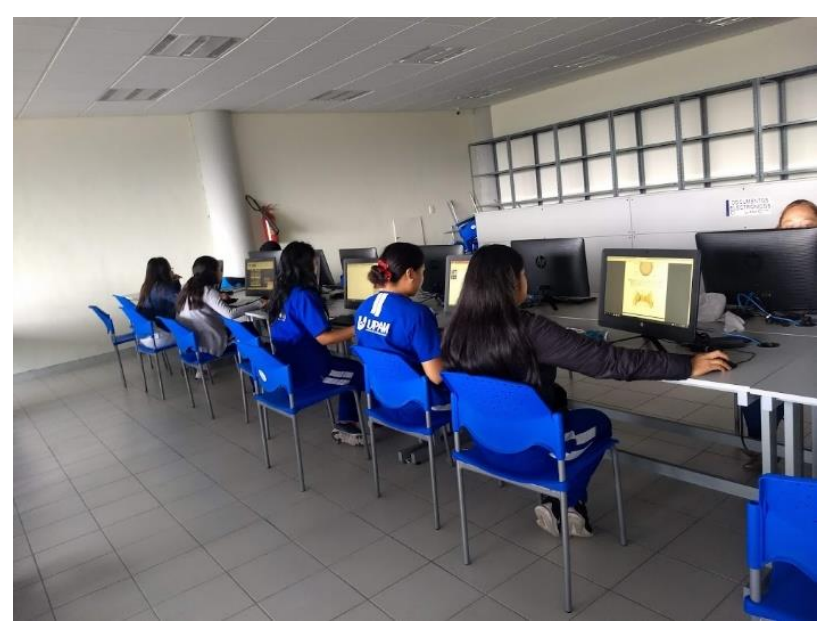

Figure 2 Elaboration of Comparative Table Source: Self Made 


\section{Module II}

In a subsequent session, phase III of the case was provided, which integrated the medical diagnosis, results and radiological studies to which the patient of the previously presented clinical case was submitted. The students had to identify and execute a workshop of special tests of evaluation in Physiotherapy and later carry out a discussion in which they provided the physiotherapeutic diagnosis and the intervention plan.

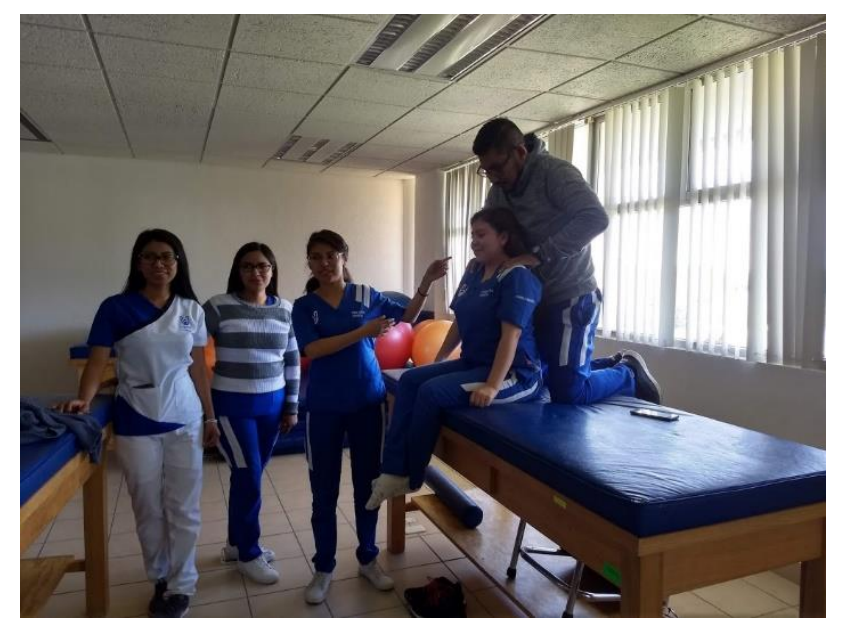

Figure 3 Assessment Workshop Source: Self Made

\section{Module III}

Session III was held in a 1-hour session in which students were informed about the objective of the execution of the teaching methodology in their academic training and the importance of their collaborative and individual work; the application of the second case was agreed.

\section{Module IV}

It was implemented in two sessions of 2 hours, in which a new case was assigned to the same teams with the same teaching methodology, with respect to the subject of the area of orthopedics in Physiotherapy. The general instructions and allocation of teaching resources were expressed to the teams; during the execution of the work, the compliance with the instructions was monitored through a competency assessment.

\section{Results}

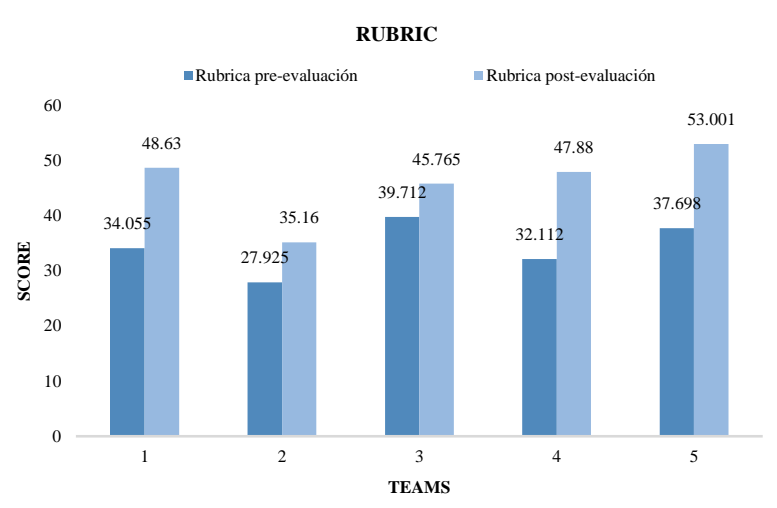

Gráfico 1 Results Pre - post rubric for the identification of the development of competencies of Clinical Practice students

Source: Self Made

With respect to the graph in the preevaluation of the teaching methodology, the students of the different teams were at a deficient level, showing difficulty in the management of information, recognition of anatomical structures, biomechanics, identification of tests in Physical Therapy and they failed to integrate the physiotherapeutic diagnosis because they were addressed to the doctor; there was also a lack of communication and adaptation skills, and commitment to work when solving problems.

After the application of the methodology, the students showed improvement in the integration of knowledge linked to the recognition of the structure, biomechanics, nociceptive and pathological characteristics of the tissues, application of tests and obtention of a diagnosis, integrating its components function structure, participation and the same factors that allowed them to elaborate a treatment plan through team work expressed in a language that revealed a good management of the information; therefore, three teams advanced to a regular level and one team advanced to satisfactory level.

\section{Conclusion}

The benefits of applying a teaching methodology in Clinical Practice are the linking of content that impacts the training of Physical Therapy students in Clinical Practice II. It promotes the development of general and disciplinary skills in their preparation, so that they can handle a disciplinary language that allows them to describe, identify, treat health problems from physiotherapy, as well as manage information and teamwork that will allow them to face new challenges. 


\section{References}

Barrio, M. J. M. (Junio 2007), Dimensiones del crecimiento humano. Revista Scielo, 10(1). Retrieved from http://www.scielo.org.co/scielo.php?pid=S0123 $-12942007000100010 \&$ script=sci_arttext

Campos, M. M. (2010). Rúbrica de evaluación en el área de la salud. Unpublished document. Archivo departamento de Quirúrgica, Facultad de Medicina, Universidad Autónoma de Puebla Cameron H.M. (2009) Agentes Físicos en Rehabilitación. $3^{\text {a }}$ Ed. Spain. Editorial Elseiver Gallego, I.T. (2007). Bases teóricas y fundamentos de la fisioterapia. Madrid Editorial Panamericana. Retrieved from books.google.com.mx/books?isbn=8479039760

Díaz B. F. y Hernández R., G. (2002). Estrategias docentes para un aprendizaje significativo. Mexico. Editorial McGraw Hill

Díaz B. A. Frida, (2003). Cognición situada y estrategias para un aprendizaje significativo, Revista Electrónica de Investigación Educativa, 5(2). Retrieved from http://redie.ens.uabc.mx/vol5no2/contenidoarceo.html

Fernández M. A. (2006). Metodologías activas para la formación de competencias. Manuscrito inédito Educatio siglo XXI, Universidad politécnica de Valencia. Retrieved from http://revistas.um.es/index.php/educatio/article/ viewFile/152/135

Huerta R. M. (2007). Aprendizaje Estratégico una necesidad del siglo XXI. Revista Iberoamericana de Educación, 42 (1). Retrieved from

http://www.rieoei.org/deloslectores/1541Huerta .pdf

Jiménez Tordoya, E. Jimmy. (2016). Guía metodológica para elaborar el diagnóstico fisioterapéutico según la Clasificación Internacional del Funcionamiento (CIF), de la discapacidad y de la salud. Gaceta Médica Boliviana, 39(1), 46-52. Retrieved from http://www.scielo.org.bo/scielo.php?script=sci_ arttext\&pid=S1012-

29662016000100011\&lng=es\&tlng=es.

Meadows J.T. Diagnóstico Diferencial en Fisioterapia. Madrid. Editorial McGraw Hill Interamericana
Monereo C. Castello M, Clariana M. Palma M, y Pérez L. (1999). Estrategias de enseñanza y aprendizaje. Barcelona. Editorial Grao

Moreno, B. M. G. (2003). Didáctica fundamentación y práctica. Mexico. Editorial Progreso, Retrieved from books.google.com.mx/books?isbn=9684362161

Moreira A. M. (1997). Aprendizaje significativo: un concepto subyacente, Manual inédito de Instituto de Física, UFRGS. Brasil. Retrieved from http://www.if.ufrgs.br/ Moreira/apsigsubesp.pd f

Navarro L. D y Samón M. M, Redefinición de los conceptos método de enseñanza y método de aprendizaje. EduSol, vol. 17, núm. 60, 2017 Centro Universitario de Guantánamo, Cuba Retrieved from http://www.redalyc.org/articulo.oa?id=4757531 84013

Pozo M. J. I. Gómez, C. M. A, (2006). Aprender y enseñar ciencia. Madrid. Editorial Morata. Retrieved from books.google.com.mx/books?isbn=8471124408

Rebollo, J. (2004). Libro Blanco Título de Grado en Fisioterapia, Agencia Nacional de Evaluación de la Calidad y Acreditación. Manuscrito inédito de la Universidad de Sevilla. Retrieved from http://www.upcomillas.es/eees/Documentos/libr oblanco_fisioterapia_ene05.pdf

Mattos.A.L(1985) Compendio de didáctica general Buenos Aires: Kapelusz.

Villalobos, P. C. (2008). Didáctica integrativa y el proceso de aprendizaje. Mexico: Editorial Trillas.

Zarzar Ch. C. (1992) Habilidades básicas para la docencia. Mexico. Editorial Patria Imagen radiográfica caso uno Retrieved from http://www.arcesw.com/radiografias.htm\#COL UMNA CERVICAL 